\title{
摇りかごによる振動刺激が新生児の 啼泣に及ぼす影響について
}

O江守 陽子, 青木 和夫, 吉田 義之（日本大学・理工）

Influence of the Whole Body by the Cradle on the Crying Infants

O Yoko Emori, Kazuo Aoki, Yoshiyuki Yoshida

(Nihon Univ. College of Sci. \& Tech.)

I・はじめに

人体に影整を及ぼす全身的な振娌刺激は、 はじめ船䐑いとして注目され、これまでは主 に不快层動として職堨瑣境や公害問題に焦点 があてられてきた。しかし、摇りかごやロッ キング・チェアに代表されるように、振動に よって快感を得られることもまたよく知られ ている。

全身振動が人体に及ぼす影䡬については、 生理学的反底の研究として主に循㻓系、呼吸 系、自律神経系等への影策が埌告されている が、その変動は正常範用内にあると言われて いる。

层動の影帮については主に成人男性を対象 に検討されており、知幼児に対する影警につ いての研究は少ない。おずかに、医亦の領域 において低出生体重児に対するウォーターベッ ドの摇れの影管をみたものがいくつか報告さ れているのみである。

本研究では、摇りかこによる低周波全身振 䖝制激を新生児に与えることによって、その 影帮を明らかにするための実験研究を行なつ た。摇りかこは、我が国においては最も沉用 されている㕕児用具の一つであり、定量的な 层動刺激を与えるのに适した裝置である。ま た、生体反底の評価には快適性の指標として 児の啼泣と、生理的指標の変化の検討を行なっ た。さらに、摇りかこという機械的・人工的 振動刺激と、保育者が抱きかかえ播するとい う、日常一般に行なわれている振動刺激に対 する反応との相違についても検討を加えた。

1. 対象

II . 方法

健康で正常な新生児、男 35 例 (53.0\%) 、 女31例 $(47.0 \%)$ 、計 66 例を対象とした。
2 ，実倹装置と测定項目（図 1）

1）尉野剌激条件

(1)加振装置

コンビ株式会社㹕スウイングラック GXK より、5分間の Z軸 (水平身長) 方向の提動 を付加した。

(2)保育者の抱㩲による剌激

立位の状態で保育者の左腕を児の後顒部と 背部に添わせるとともに、左腕と保育者の躯 軒で児体重を保持しながら水平 ( $\mathrm{Z}$ 軸) 方向 の振動を 5 分間付加した。

2）生理的指標の测定装置

アトム株式会社製ネオナータルモニタ 63

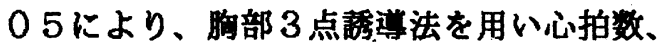
呼吸数、末梢体表面温度を测定した。心電図 はTEAC社製カセット・データレコーダー R 61 により連続欩録した後、その変動係数 を求めた。

3）児の状態の钼察

実駿時の児の行動状態をPrechtlの判定基 準にしたがつて 5 段階評価した。児の反底に ついてはチェックリストにより同一験者が钼 察した。

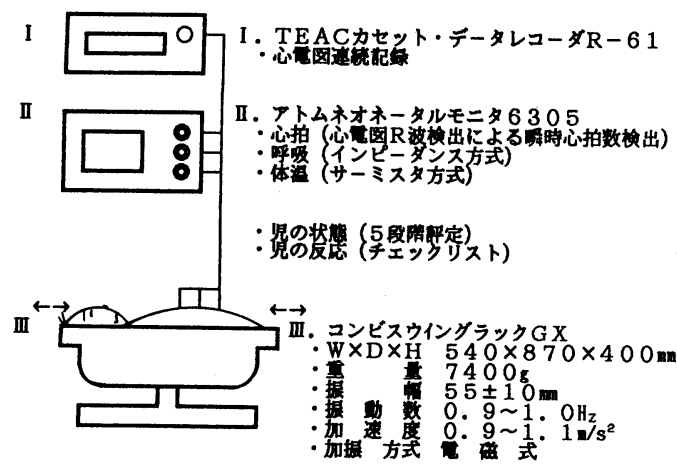

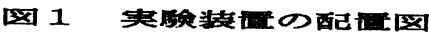




\section{3. 実驗手順}

児に心拍数、呼吸数、皮席温度测定のため の電極類を装着した。すべての準備が終了し た後に安静 5 分間、提助刺做 5 分間、再び安 静 5 分間をとつた。保育者の抱攡による层娌 刺激は、摇りかこによる振野刺激と同様の手 順で行なった。

心拍数、呼吸数、体温、児の覚醒状態は捺動 開始前安静俌として最終の5 分书を、振動中 は 1 分ごとの平均値を、また、終了後安静値 は 1、3、5 分値の各平均値を用いた。 児の反応については連続して観察した。CV $R-R$ 分間偪の心電図 $\mathrm{R}$ 波間隔の平均を用いた。

\section{III. 結果および考察}

\section{1. 振動前後の啼泣の変化（表 1 )}

振動開始前に啼泣がみられ、振動開始とと もに啼泣が停止したものを有効群、振動開始 前、振動中とも啼泣が認められ、振動刺激に よる変化が認められなかつたものを無効群、 振動開始前、振動中ともに啼泣がみられず変 化のみられなかつたものを対照群、また、分 類不能はその他とした。

無効群 3 例に対し有効群は16例となり、摇 りかごによる振動刺激は児の啼泣を停止させ る効果があるといえる。

\section{2.啼泣停止までに要した時間}

有効群のうち、振動開始から啼泣停止まで に要した時間をみると、平均 $24.6 \pm 31.6$ 秒で、 開始後早期に効果が認められたといえる。

\section{3. 振動刺激と児の反応との関係}

有効群では開始前に児が示した反応の種類 は 7 項目で延べ数51件であつた。层動中は開 始前に比へてて半減し、終了後は開始前より增 加した。 1 振㽖方楼

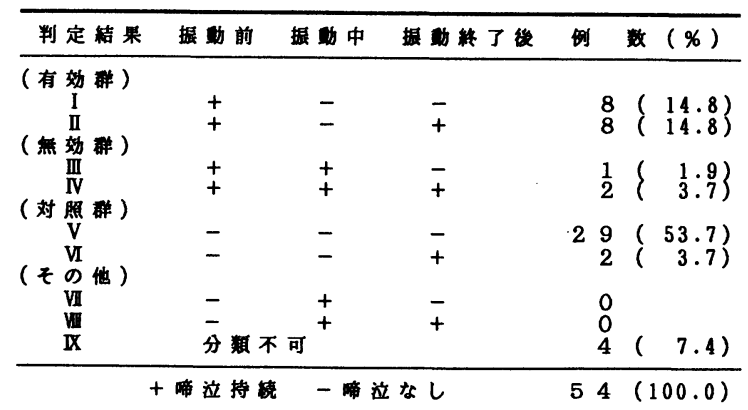

対照群では、開始前が最も少なく振䡃中は開 始前に比べて約 2 倍に增加し、終了後は更に 增加した。また、振動中は両群に神経行動学 的に锐敏で清明な状態とされている「注視」 が钼察され、これは、振䡃が児にとつて新た な興味や関心を示す强い外界からの刺激とし て受け止められた可能性を示唆した。

\section{4.振動刺激と児の生理的指標との関係}

有効群では心拍数は振動開始前が最も高く、 层動中には有意な減少が認められた。対照群 では、開始前、振野中ともにほとんど変化が 認められなかつたが、終了後はわずかに娍少 した。また、呼吸数は有効群で振動開始前よ り振動中にやや增加し、終了後は再び減少し た。対照群も有効群と同棣の㑯向を示したが、 開始前と終了後に比べて尉動中の堌加が大き かった。このことから、本研究で用いた振動 は児にとって大きな剌激であつたことを推察 させた。末梢体表面温度は、有効群も対照群 もともに開始前、振動中、終了後と徐々に下 降が認められた。このことから、摇りかごの 振動刺激は有効群、対照群ともに末梢血管を 収縮させたと考えられた。

5.摇りかこと保育者の抱擁による振動刺激 の生理的指標の比較

心拍数は抱攡群では終了後も振動中と同様 に低値を示した。また、抱攡群では振動開始 前の呼吸数が最も多く、振動中、振動終了後 とやや減少する傾向にあり、開始前と終了後 を比較すると後者に有意な減少が認められ、 有効群と同様の傾向を示した。一方、末梢体 表面温度は開始前に最も低く、振動中、終了 後と徐々に堌加する㑯向が認められ、この点 が摇りかこによる機械的振動刺激と最も相違 のみられた結果であった。

\section{IV.まとめ}

摇りかごによる振動刺激が新生児の啼泣と 生体に及ぼす影祭について検討した。

その結果、本研究で用いた振動条件下での 摇りかごの全身振動は啼泣している児をなき 止ませ、鎮静化に導くことが確認されたが、 睡眠、及びまどろみ状態にあった児に対して は党醒へと導く強い刺激となることから、日 常利用する場合にはその目的により使い分け る必要があると考えられた。 